\title{
Review of Photochemical Smog Pollution in Jakarta Metropolitan, Indonesia
}

\author{
Dollaris R. Suhadi, M. Awang, M.N. Hassan, Ramdzani Abdullah and Azizi Hj. Muda \\ Department of Environmental Management, Faculty of Environmental Studies, \\ Universiti Putra Malaysia, 43400 UPM Serdang, Selangor, Malaysia
}

\begin{abstract}
An analysis of photochemical smog pollution in Jakarta was attempted using data from the existing air quality monitoring stations. Ground-level ozone potential is high in Jakarta due to the high traffic emissions of ozone precursors and the favorable surface meteorological conditions. Despite the frequent missing data during the 1996-1999 monitoring, which resulted in lower ozone values, ozone episodes were significantly recorded in 1997-1998. The number of hours on which ozone concentrations exceed the 1-hour standard (100 ppb) at an ambient station located in Kelapa Gading (10 km northeast of city center) was 186 hrs in 1997 and 571 hrs in 1998. El Niño phenomenon in 1997-1998 had affected the local meteorology leading to more favorable conditions for photochemical production of ozone. The annual ozone averages in ambient stations located off the city center have exceeded the 1-year standard limit $(15 \mathrm{ppb})$. Although the annual average and 95-percentile values indicated an increasing trend from 1996 to 1998, the trend remains to be seen in the future as more complete data could be expected from the new monitoring system. The number of hours on which ozone exceed the 1-hour standard and the annual average tend to be increasing since 2001 to 2002 in all 3 newly operated stations. The seasonal variations of ozone indicate that ozone level is highest in the dry season (September-November) and is lowest in the wet season (December-March). Correlation between ozone level and meteorological attributes (solar radiation, relative humidity and temperature) was significant at 0.01 confidence level. The diurnal cycle of ozone and its precursors is clearly shown and is typical for polluted urban areas. Improvement of the database of air quality monitoring is very critical for Jakarta. Through better database management, the development and monitoring of cost-effective air pollution control strategy can be made.
\end{abstract}

Key words: Ozone, Ozone Precursors, Traffic Emissions, Meteorological Conditions

\section{INTRODUCTION}

Photochemical smog is a condition that develops when primary pollutants (oxides of nitrogen- $\mathrm{NO}_{\mathrm{x}}$ and volatile organic compounds-VOC created from burning of fossil fuels and biomass) interact in the presence of sunlight to produce a mixture of hazardous secondary pollutants [1]. The major constituent of photochemical smog is ground-level ozone $\left(\mathrm{O}_{3}\right)$, which is not emitted directly into the atmosphere but formed as the product of photochemical reactions of precursors, $\mathrm{NO}_{\mathrm{x}}$ and VOC [2]. Basic photochemical cycle of $\mathrm{NO}, \mathrm{NO}_{2}$ and $\mathrm{O}_{3}$ involves the following reactions: when $\mathrm{NO}$ and $\mathrm{NO}_{2}$ are present in sunlight, ozone formation occurs as a result of the photolysis of $\mathrm{NO}_{2}$ at wavelength $<424 \mathrm{~nm}$,

$\mathrm{NO}_{2}+\mathrm{hv} \rightarrow \mathrm{NO}+\mathrm{O}$

$\mathrm{O}+\mathrm{O}_{2}+\mathrm{M} \rightarrow \mathrm{O}_{3}+\mathrm{M}$

where, $\mathrm{M}$ represents $\mathrm{N}_{2}$ or $\mathrm{O}_{2}$ or another third molecule that absorbs the excess energy and thereby stabilize the $\mathrm{O}_{3}$ molecule. There are no other significant sources of $\mathrm{O}_{3}$ in the atmosphere other than reaction (2). Once formed, $\mathrm{O}_{3}$ reacts with $\mathrm{NO}$ to regenerate $\mathrm{NO}_{2}$.
$\mathrm{O}_{3}+\mathrm{NO} \rightarrow \mathrm{NO}_{2}+\mathrm{O}_{2}$

Development of photochemical smog is typically associated with specific climatic conditions. Local meteorological factors that influence the formation of photochemical smog include solar radiation, cloud cover, temperature and precipitation. Other factors such as wind speed, mixing height and topography determine the dispersion of $\mathrm{O}_{3}$ in the boundary layer. High temperatures are frequently associated with high pressure, stagnant conditions that lead to suppressed vertical mixing and increased $\mathrm{O}_{3}$ levels.

The database of ground-level ozone observations for urban and suburban areas indicates that at most rural sites, ozone concentrations have been found to vary over a diurnal cycle with a minimum in the early morning hours before dawn and a maximum in the late afternoon [2]. This pattern results from daytime photochemical production or intrusion of ozone from upper layer to the boundary layer, combined with ozone loss by dry deposition and reaction with nitric acid (NO) at night, when photochemical production ceases and vertical transport is inhibited by a temperature inversion. In urban areas the nocturnal minimum in

Corresponding Author: Dollaris R. Suhadi, Department of Environmental Management, Faculty of Environmental Studies, Universiti Putra Malaysia, 43400 UPM Serdang, Selangor, Malaysia

Tel: +60-12-2641 E-mail: DSuhadi@ssafara.net 
ozone can be quite evident because of the rapid reaction between $\mathrm{O}_{3}$ and NO.

This study reviews the status of photochemical smog pollution in Jakarta Metropolitan during a period of 7 years, 1996-2002 with focus on ozone and $\mathrm{NO}_{\mathrm{x}}$ pollutants. Average monthly and diurnal concentrations of ozone and its precursor are also evaluated in relation to variations in meteorological conditions.

\section{STUDY AREA AND DATA COLLECTION}

Jakarta is the capital city of Indonesia located in the northern part of Java Island, at $106^{\circ}$ East and $6^{\circ}$ South. The area of Jakarta is approximated at 664 square kilometers with flat topography, close to the shore and has an average elevation of 7 meter above sea level. Jakarta is part of the greater Jabodetabek (Jakarta, Bogor, Depok, Tangerang and Bekasi); bordering with Tangerang in the west, with Bogor and Depok in the south and Bekasi in the east. The total population of Jakarta was estimated at 9 million in 2002, whereas total population of Jabodetabek exceeded 22 million people in 2002. In the meantime, total commuters from Bodetabek to Jakarta today exceed 3 million everyday. Climate in Indonesia is largely influenced by monsoon systems, both Asia and Australian winter monsoons. During wet months (October-March), wind direction extends from west to southwest transporting moist air from Asia continent; while during dry months (April-September) wind direction is from north up to northeast which transports dry air from southern hemisphere. Besides the monsoon systems, the climate is also affected by global circulation occurring on a time scale of several years known as El Niño/Southern Oscillation (ENSO). In 1997, extreme meteorological values were recorded in Indonesia and the region as a result of ENSO phenomenon. The climate in Jakarta is very hot and humid. Because Jakarta lies so close to the equator, the solar heating during the day and the earth cooling during the night may produce local land-sea breeze. The winds are generally weak. Calm conditions often prevail at night. In the afternoon, winds are quite moderate because of the effects of local winds that modify the monsoon winds.

Jakarta has experienced serious air pollution problem, which is largely contributed from traffic sources accounting for approximately $70 \%$ of the total emissions. The vehicular emissions in Jakarta contributed $69 \%$ of total NOx emissions, whereas CO and $\mathrm{HC}$ emissions from vehicular sources amount to 564,000 ton and 98,000 ton per year respectively [3].

The data used for this study were collected from the Local Environmental Management Agency (BPLHD) of DKI Jakarta and the National Environmental Management Center (EMC). During a period of 1996-1999, data was supplied from an air quality monitoring network which comprises of 6 stations that monitor $\mathrm{NO}_{\mathrm{x}}, \mathrm{CO}, \mathrm{PM}_{10}, \mathrm{NMHC}, \mathrm{THC}, \mathrm{O}_{3}$ and $\mathrm{SO}_{2}$ parameters using designated absorption methods. In 2000, the prevailing stations were overhauled and

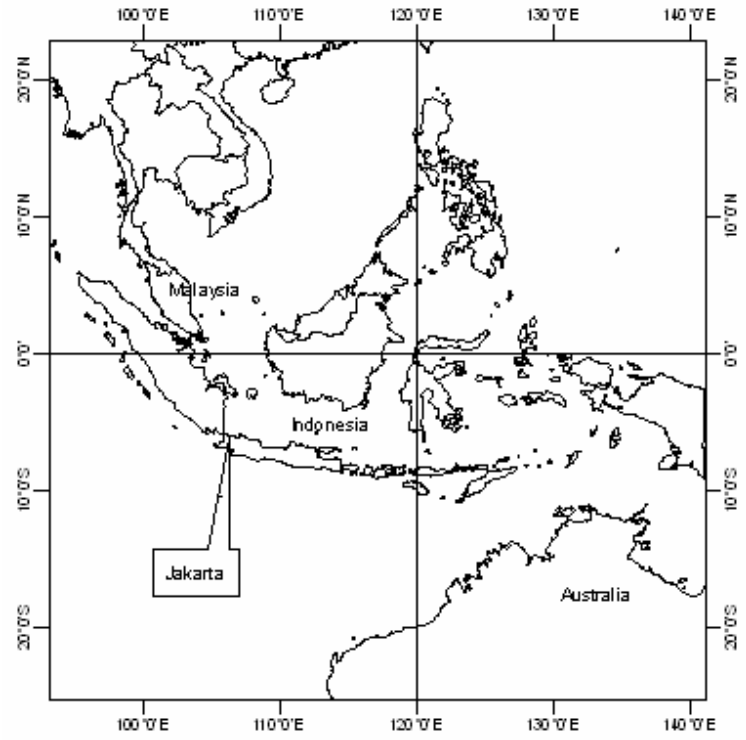

Fig. 1: Map of Indonesia

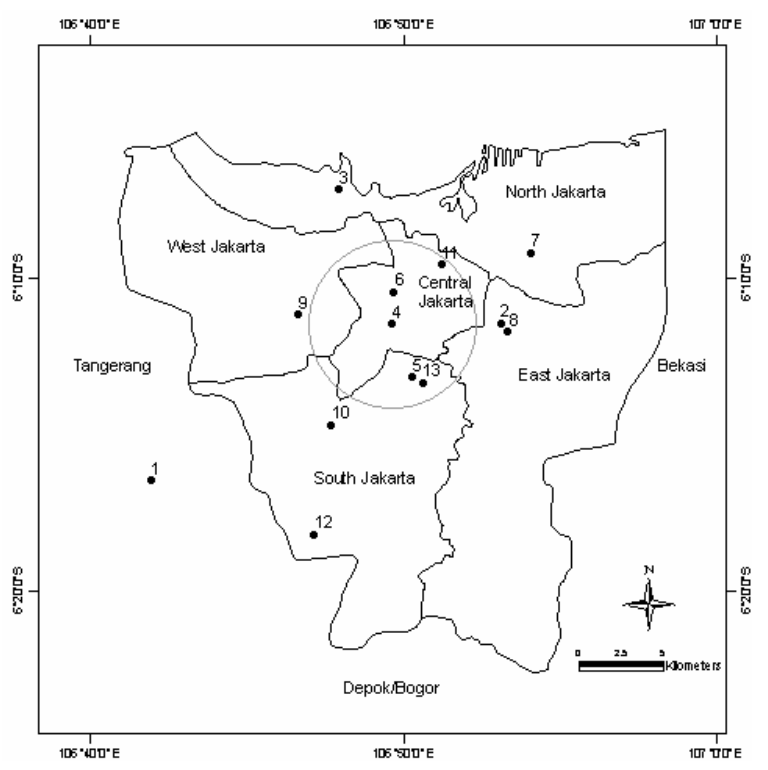

Fig. 2: The Area of Jakarta and Air Quality Monitoring Locations with Station No.4 Being Located in the City Center

replaced with the new monitoring stations, which are operated automatically from the central computers at the BPLHD. Two 2 new stations started operating in 2001 while the remaining 3 stations started operating in the following year. These new stations are equipped with measurement analyzers to monitor $\mathrm{NO} / \mathrm{NO}_{2}, \mathrm{SO}_{2}$, $\mathrm{CO}, \mathrm{O}_{3}$ and $\mathrm{PM}_{10}$. Specifically, hourly data of $\mathrm{O}_{3}, \mathrm{NO}$, $\mathrm{NO}_{2}, \mathrm{CH}_{4}, \mathrm{NMHC}$ and $\mathrm{CO}$ from both monitoring network were used as the basis for this analysis. Meteorological data was compiled from 2 major stations, namely Cengkareng International Airport and Curug Airstrip. In addition, In Situ meteorological data is also recorded at air quality monitoring 
Table 1: Monitoring Locations and Year of Data Recorded

\begin{tabular}{|c|c|c|c|c|c|c|c|c|}
\hline Name & Location & 96 & 97 & 98 & 99 & 00 & 01 & 02 \\
\hline EMC (1) & Serpong, southwest of Jakarta. No nearby specific emission sources. & & - & $\bullet$ & - & - & & \\
\hline Pulogadung (2) & East Jakarta, industrial park. & & • & • & • & & & \\
\hline Pluit (3) & North Jakarta, residential area. & • & • & - & • & & & \\
\hline Thamrin (4) & Central Jakarta, at curbside near Thamrin roundabout. & $\bullet$ & $\bullet$ & $\bullet$ & $\bullet$ & & & \\
\hline Casablanca (5) & Central Jakarta, commercial and residential area. & & - & - & - & & & \\
\hline Gambir (6) & Central Jakarta, at curbside. & - & • & • & & & & \\
\hline Kelapa Gading (7) & North Jakarta, residential area. & & • & & & & & \\
\hline Pulogadung* (8) & East Jakarta, industrial park. & & & & & & $\bullet$ & $\bullet$ \\
\hline Kebon Jeruk* (9) & West Jakarta, commercial and residential area. & & & & & & & • \\
\hline Senayan* (10) & South Jakarta, commercial area & & & & & & & • \\
\hline Kemayoran* (11) & Central Jakarta, commercial area & & & & & & & - \\
\hline Pondok Indah* (12) & South Jakarta, commercial and residential area. & & & & & & & • \\
\hline BPLHD* (13) & South/central Jakarta, commercial and residential area & & & & & & • & • \\
\hline
\end{tabular}

*New monitoring stations (2000-present)

Source: BPLHD DKI Jakarta, 2001

Table 2: Emission Standards for $\mathrm{O}_{3}$ and $\mathrm{NO}_{2}$ for Jakarta

\begin{tabular}{|c|c|c|c|}
\hline & 1 hour & 24 hour & 1 year \\
\hline $\mathrm{NO}_{2}$ & $2400 \mu \mathrm{g} \mathrm{m}^{-3}(200 \mathrm{ppb})$ & $92.5 \mu \mathrm{g} \mathrm{m}^{-3}(50 \mathrm{ppb})$ & $60 \mu \mathrm{g} \mathrm{m}^{-3}(30 \mathrm{ppb})$ \\
\hline $\mathrm{O}_{3}$ & $200 \mu \mathrm{g} \mathrm{m}^{-3}(100 \mathrm{ppb})$ & - & $30 \mu \mathrm{g} / \mathrm{m}^{-3}(15 \mathrm{ppb})$ \\
\hline
\end{tabular}

stations, which are equipped with basic meteorological sensors at $10 \mathrm{~m}$ height above the ground.

\section{RESULTS AND DISCUSSION}

Status of Ozone Pollution: Table 3 through 6 present a summary of ozone and $\mathrm{NO}_{2}$ pollution levels for Jakarta during the four-year monitoring period from 1996 to 1999 and the two-year period from 2001 to 2002. In general, the highest ozone was found at ambient station number 7 (Kelapa Gading) located approximately $10 \mathrm{~km}$ northeast of the city center. The highest hourly maximum level was recorded at $964 \mathrm{ppb}$ at this station. Although this figure looks highly suspicious as if someone was doing a range check on the ozone instrument, it was noted that the total number of hours on which ozone exceed the standard were quite high reaching $186 \mathrm{hrs}$ and $570 \mathrm{hrs}$ in 1997 and 1998 respectively. Station 7 also held the highest average hours per year of ozone exceeding the standard, followed with station 2 and 3 . Where ozone data are available in 1996-1999, 1998 was characterized by the highest ozone values (average and 95 percentile) at station 2. At stations 3 and 7 , the highest ozone values were recorded in 1997. The discussion on the relation between ozone episodes and the El Niño phenomenon during 1997-1998 is discussed later in the next section. Lower ozone was detected at curbside station 4 and ambient station 5 of which these stations are located closest to the city center. The major factor that caused low ozone values at these stations was due to destruction of ozone by NO. Since most of the $\mathrm{NO}_{\mathrm{x}}$ is emitted in the form of NO, it can be expected that with high emission of NO from traffic in curbside station, ozone level becomes lower (reaction 3). The processes of destruction and formation of ozone in a large urban

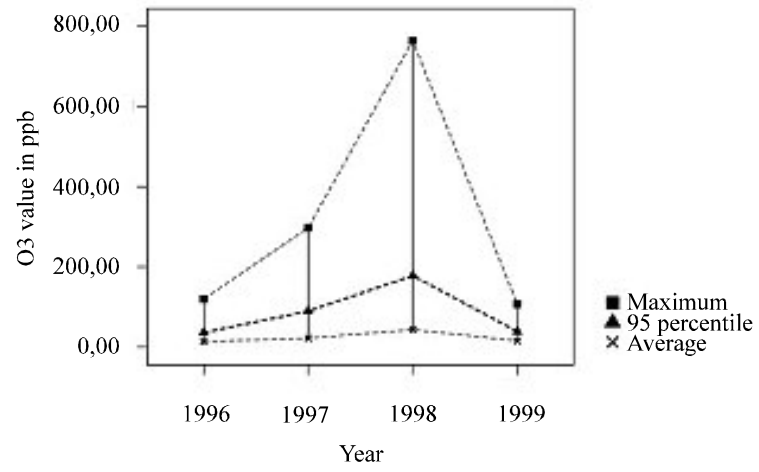

Fig. 3: $\mathrm{O}_{3}$ Annual Trend Averaged for 3 Stations (Station 2, 3 and 7)

area such as Jakarta should be competing at any location. Over the city, ozone level is found to be relatively high except at the very heavy traffic city center and curbside where the ozone destruction by NO is very apparent. However, it is very difficult to make further assessment as to the transport of ozone and its precursors over the larger area of Jakarta (beyond the $15 \mathrm{~km}$ perimeter of the city center) because all stations are located within.

Frequent missing data and limitation of the current two-year monitoring (2001-2002) make the assessment of ozone annual trend very premature. The initial ozone trend averaged for 3 ambient stations (station 2, 3 and 7) indicated an increase of ozone values from 1996 to 1999; but a substantial drop was noted from 1998 to 1999 (Fig. 3). The substantial drop of ozone level was significantly contributed from station 7 . Thus, besides the low percentage of data completeness, other factors such as the change in meteorological conditions and in emission of $\mathrm{O}_{3}$ precursors in the upwind area of station 7 may also play a role in causing the shift of ozone annual trend. In addition, the annual ozone averages in ambient stations located off the city center (station 2, 3 and 7) indicated exceeding the 1-year standard limit (15 ppb). Ozone fluctuation in terms of standard deviation was quite high showing variations in daily and monthly time scales. 
Am. J. Environ. Sci., 1(2): 110-118, 2005

Table 3: Ozone Pollution Level Exceeding the Jakarta Air Quality Standard (1996-1999, 2001-2002)

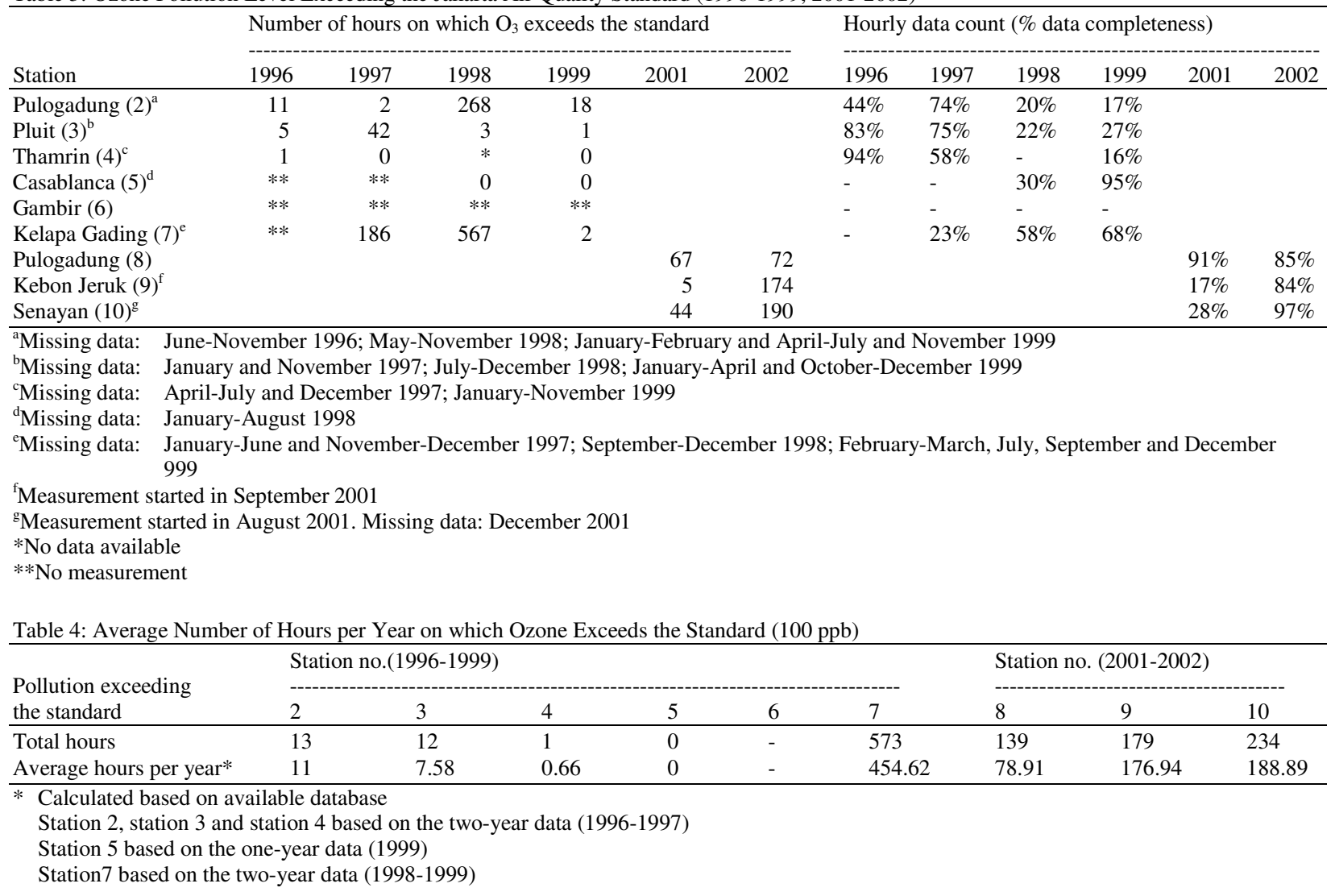

The assessment of ozone level in the background area (station 1) was not done due to unavailability of ozone data. It can be expected that $\mathrm{O}_{3}$ concentration in this background area is fairly high. Rural environments tend to be characterized by relatively high VOC-to- $\mathrm{NO}_{\mathrm{x}}$ ratios because of rapid removal of $\mathrm{NO}_{\mathrm{x}}$ from distant sources compared to that of VOC [2]. In general, increasing VOC concentrations means more ozone. Transport of ozone from a very photochemically active source region (Jakarta urban center) is also a possible candidate of potential source of ozone enhancement in the background area.

For the current air quality monitoring which uses telemetric equipment, the number of hours on which ozone exceeds the standard indicated a steady increase since 2001 to 2002 in all three new stations. Although the trend remains to be seen in the future, the potential for ozone episodes in Jakarta metropolitan and its surrounding area of Bodetabek is very high. Given the fact that no counter measures are put in place to reduce air pollution at this time, an increasing trend of ground ozone pollution is very likely in the immediate future, as the emission of ozone precursors from traffic source remains high.

Ozone Seasonal Variations and Related Meteorological Conditions: Table 7 presents the total number of hours on which ozone exceeds $100 \mathrm{ppb}$ at stations 2, 3 and 7. High ozone levels were generally recorded in May-September (dry months). Maximum monthly ozone averages at station 2 over 4 years were 47.28 $\pm 11.49 \mathrm{ppb}$ (in June 1996), 21.11 $\pm 11.44 \mathrm{ppb}$ (in May 1997), 148.92 \pm 201.02 ppb (in December 1998) and 72.61 $\pm 14.3 \mathrm{ppb}$ (in July 1999). At station 3, maximum monthly average was recorded in July 1996, July 1997, January 1998 and June 1999 with values of $22.78 \pm 19.32 \mathrm{ppb}, 25.28 \pm 25.72 \mathrm{ppb}, 19.83 \pm 21.60 \mathrm{ppb}$ and $24.91 \pm 18.06 \mathrm{ppb}$ respectively. Monitoring at station 7 showed highest monthly average in July 1997 (166.03 $\pm 217.98 \mathrm{ppb})$, in September 1998 (77.03 \pm 53.23 ppb) and in September 1999 (11.46 \pm 7.12 ppb). Overall, standard deviation is high showing high fluctuation of ozone in monthly time scale. Figure 4 shows monthly average ozone value at station 8 in 2001-2002. The selection of this station is primarily due to relatively higher percentage of data completeness for two consecutive years. Although the annual cycle is not clearly shown, maximum ozone value is generally recorded during the September-November period. From December to March (wet season), ozone levels are minimum. Figure 4 also illustrates a constant increase of ozone concentration over two years from 2001 to 2002.

Ozone behavior near the surface may be attributed to local meteorological conditions [4]. During the period of 1997-1999, daily mean temperature was increasing 
Am. J. Environ. Sci., 1(2): 110-118, 2005

Table 5: $\mathrm{NO}_{2}$ Pollution Level Exceeding the one hour and 24 hour Air Quality Standard (200 ppb and $\left.50 \mathrm{ppb}\right)$

\begin{tabular}{|c|c|c|c|c|c|c|c|c|c|c|c|c|}
\hline \multirow[b]{3}{*}{ Station } & \multicolumn{12}{|c|}{ Number of exceedances } \\
\hline & \multicolumn{2}{|l|}{1996} & \multicolumn{2}{|l|}{1997} & \multicolumn{2}{|l|}{1998} & \multicolumn{2}{|l|}{1999} & \multicolumn{2}{|l|}{2001} & \multicolumn{2}{|l|}{2002} \\
\hline & Hours & Days & Hours & Days & Hours & Days & Hours & Days & Hours & Days & Hours & Days \\
\hline $\begin{array}{l}\text { Pulogadung }(2)^{\mathrm{a}} \\
\end{array}$ & 0 & 0 & 1 & 3 & 0 & 6 & 0 & 0 & & & & \\
\hline Pluit (3) ${ }^{\mathrm{b}}$ & 1 & 0 & 1251 & 125 & 295 & 96 & 8 & 0 & & & & \\
\hline Thamrin $(4)^{\mathrm{c}}$ & 24 & 26 & 1372 & 269 & 427 & 119 & 3 & 1 & & & & \\
\hline Casablanca $(5)^{\mathrm{d}}$ & 1 & 5 & 6 & 21 & 18 & 10 & 2 & 1 & & & & \\
\hline Gambir $(6)^{e}$ & 258 & 48 & 30 & 99 & 5 & 147 & * & * & & & & \\
\hline Kelapa Gading (7) & $* *$ & $* *$ & 0 & 3 & 0 & 0 & $*$ & $*$ & & & & \\
\hline Pulogadung $(8)^{\mathrm{f}}$ & & & & & & & & & 0 & 0 & 0 & 0 \\
\hline Kebon Jeruk $(9)^{g}$ & & & & & & & & & 0 & 0 & 80 & 62 \\
\hline Senayan $(10)^{\mathrm{h}}$ & & & & & & & & & $*$ & $*$ & 18 & 39 \\
\hline
\end{tabular}

\begin{tabular}{|c|c|c|c|c|c|c|c|c|}
\hline & & \multicolumn{7}{|c|}{ Hourly data count (\% data completeness) } \\
\hline & & 1996 & 1997 & \multicolumn{2}{|c|}{1998} & 1999 & 2001 & 2002 \\
\hline Pulogadung $(2)^{\mathrm{a}}$ & & $93 \%$ & $84 \%$ & 18 & & $80 \%$ & & \\
\hline Pluit $(3)^{\mathrm{b}}$ & & $86 \%$ & $79 \%$ & 42 & & $32 \%$ & & \\
\hline Thamrin $(4)^{\mathrm{c}}$ & & $97 \%$ & $72 \%$ & $39^{c}$ & & $70 \%$ & & \\
\hline Casablanca $(5)^{\mathrm{d}}$ & & $87 \%$ & $87 \%$ & 83 & & $95 \%$ & & \\
\hline Gambir $(6)^{\mathrm{e}}$ & & $54 \%$ & $83 \%$ & 10 & & - & & \\
\hline Kelapa Gading (7) & & - & $15 \%$ & 62 & & - & & \\
\hline Pulogadung $(8)^{\mathrm{f}}$ & & & & & & & $65 \%$ & $82 \%$ \\
\hline Kebon Jeruk $(9)^{g}$ & & & & & & & $29 \%$ & $78 \%$ \\
\hline Senayan $(10)^{\mathrm{h}}$ & & & & & & & - & $77 \%$ \\
\hline \multicolumn{9}{|c|}{ 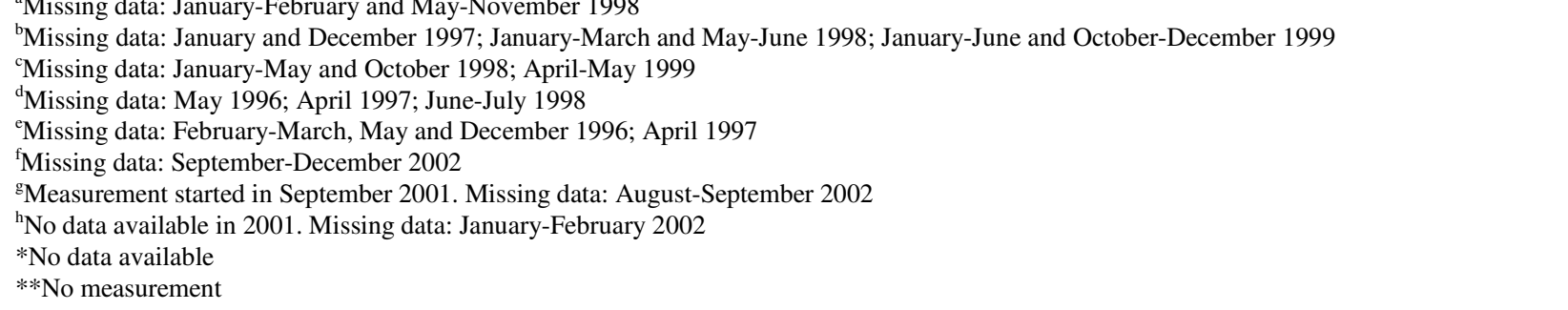 } \\
\hline \multicolumn{9}{|c|}{ Table 6: Summary of Annual Ozone Values (1996-1999, 2001-2002) } \\
\hline \multirow[b]{2}{*}{ Station } & \multirow{2}{*}{\multicolumn{2}{|c|}{ Year }} & \multicolumn{5}{|c|}{ Value in $\mathrm{ppb}$} & \multirow[b]{2}{*}{ Data count } \\
\hline & & & Average $\pm 1 \mathrm{SD}$ & Minimum & Maximum & Median & 95-percentile & \\
\hline \multirow[t]{4}{*}{ Pulogadung (2) } & 1996 & & $17.52 \pm 13.63$ & 1 & 129 & 14 & 43 & 3836 \\
\hline & 1997 & & $14.4 \pm 13.16$ & 0 & 161 & 11 & 40 & 6455 \\
\hline & 1998 & & $67.36 \pm 142.33$ & 0 & 993 & 16 & 363.95 & 1762 \\
\hline & 1999 & & $46.79 \pm 20.83$ & 0 & 122 & 40 & 85 & 1505 \\
\hline \multirow[t]{4}{*}{ Pluit (3) } & 1996 & & $10.9 \pm 11.43$ & 0 & 115 & 7 & 32 & 7320 \\
\hline & 1997 & & $17.77 \pm 18.57$ & 0 & 228 & 11 & 53 & 6564 \\
\hline & 1998 & & $12.79 \pm 13.45$ & 0 & 148 & 9 & 38 & 1965 \\
\hline & 1999 & & $12.09 \pm 14.38$ & 0 & 101 & 6 & 39 & 2386 \\
\hline \multirow[t]{3}{*}{ Thamrin (4) } & 1996 & & $9.66 \pm 9.91$ & 0 & 104 & 7 & 30 & 8254 \\
\hline & 1997 & & $5.1 \pm 5.45$ & 0 & 78 & 4 & 14 & 5050 \\
\hline & 1999 & & $8.08 \pm 0.58$ & 0 & 88 & 3 & 31 & 1352 \\
\hline \multirow[t]{2}{*}{ Casablanca (5) } & 1998 & & $7.43 \pm 11.87$ & 0 & 88 & 2 & 38 & 2565 \\
\hline & 1999 & & $7.51 \pm 10.59$ & 0 & 76 & 2 & 31 & 8326 \\
\hline \multirow[t]{3}{*}{ Kelapa Gading (7) } & 1997 & & $57.27 \pm 122.73$ & 0 & 964 & 20.6 & 366.35 & 2007 \\
\hline & 1998 & & $46.53 \pm 82.09$ & 0 & 923.6 & 17.7 & 167.56 & 5097 \\
\hline & 1999 & & $8.52 \pm 9.74$ & 0 & 105.2 & 5.7 & 26.6 & 5944 \\
\hline \multirow[t]{2}{*}{ Pulogadung (8) } & 2001 & & $16.83 \pm 21.47$ & 0 & 280.25 & 7 & 60.05 & 7967 \\
\hline & 2002 & & $25.79 \pm 21.12$ & 3.64 & 279.43 & 14.57 & 69.49 & 7464 \\
\hline \multirow[t]{2}{*}{ Kebon Jeruk (9) } & 2001 & & $16.45 \pm 17.54$ & 0.98 & 139.60 & 8.28 & 61.09 & 1478 \\
\hline & 2002 & & $28.95 \pm 25.35$ & 0.26 & 217.15 & 17.14 & 82.97 & 7384 \\
\hline \multirow[t]{2}{*}{ Senayan (10) } & 2001 & & $19.14 \pm 24.24$ & 0 & 151.71 & 7.22 & 73.60 & 2475 \\
\hline & 2002 & & $26.82 \pm 24.19$ & 0.39 & 203.11 & 17.98 & 80.74 & 8377 \\
\hline
\end{tabular}




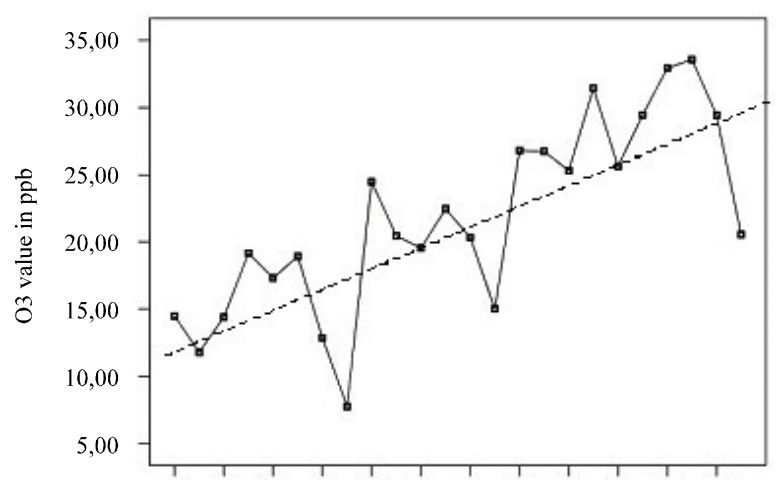

Jan Mar May Jul Sep Nov Jan Mar May Jul Sep Nov

Month (Jan 2001-Dec 2002)

Fig. 4: Monthly Average $\mathrm{O}_{3}$ Value at Station 8 (2001-2002)

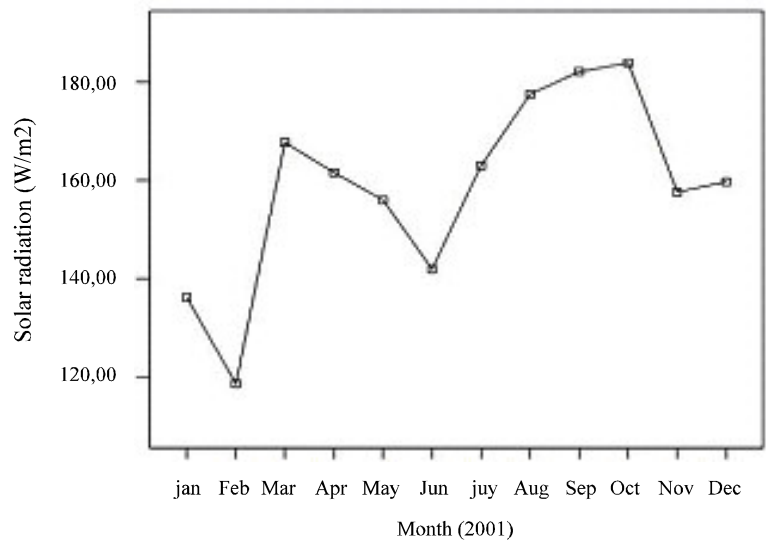

Fig. 5:Monthly Average Solar Radiation (In Situ Station 8), 2001

in 1997 and continued to increase towards 1998. Lowest humidity was recorded in October 1997 with $75 \%$ of relative humidity. Higher mean temperature and lower relative humidity in 1997 were associated with the El Niño phenomenon in that year. Particularly, strong El Niño extended from July 1997 to April 1998. In 1998 and 1999, the meteorological conditions returned to their normal averages (calculated based on a minimum 10 year meteorological observation).

Wind direction extends mostly from west to southwest during November-March, except in January where wind direction is from west to north. Calm conditions significantly prevail in the months of May through October with frequency ranging from 18 to $26 \%$. In addition, the NE wind balances the calm winds during that period, specifically in the months of July through Sept. The calm conditions are in favor of ozone enhancements in Jakarta during May-October (dry months). Local biomass burning is often active in dry months, especially towards the end of dry season, potentially contributing to maximum ozone.

In addition, In Situ meteorological observation at station 8 in 2001 Fig. 5 to 7 may explain the association

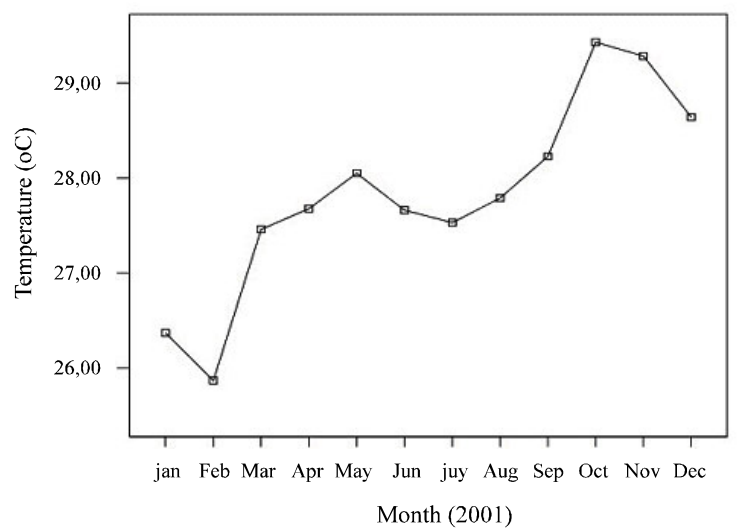

Fig. 6: Monthly Average Temperature (In Situ Station 8), 2001

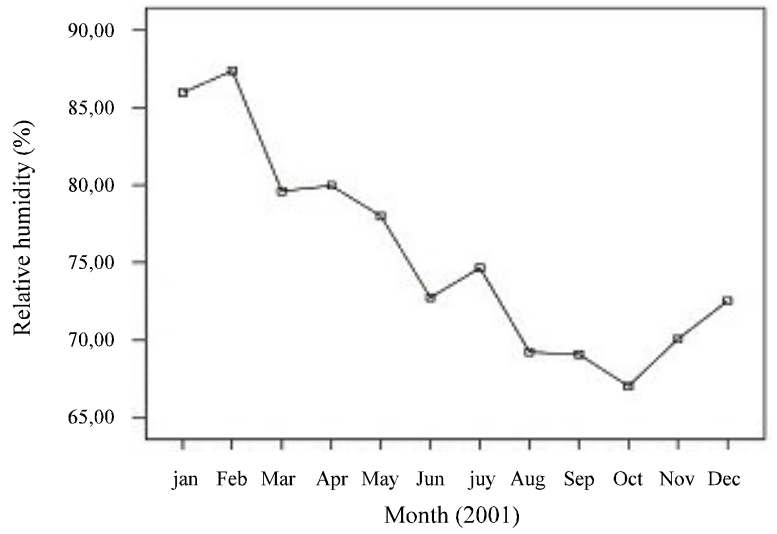

Fig. 7: Monthly Average Relative Humidity (In Situ Station 8), 2001

of high ozone levels Fig. 4 with warm temperatures, low humidity and high solar radiation. The local land-sea breeze may potentially influence ozone behavior in the area. Analysis of correlation using the two-year database at station 8 indicated that the correlation between ozone and solar radiation, between ozone and temperature and between ozone and humidity was all significant at the 0.01 level (two-tailed student $\mathrm{t}$ test) with the correlation coefficient ( $\mathrm{r}$ ) of $0.64,0.67$ and 0.63 , respectively.

Surface meteorological observation indicates that the southerly to NE wind predominates over the period of May-October (dry season) transporting the ozoneenriched air masses towards neighboring Southeast Asian countries. Zhang et al. related the high ozone in the dry season in Bangkok to, among others, the regional transport of $\mathrm{O}_{3}$ and precursors from the Asian continent associated with the NE monsoon.

Ozone Diurnal Cycle: Diurnal variations of ozone and its precursors for the selected stations were analyzed. Stations 8, 9 and 10 were selected for ozone diurnal analysis as they have relatively less missing data. However, the new monitoring system does not measure 


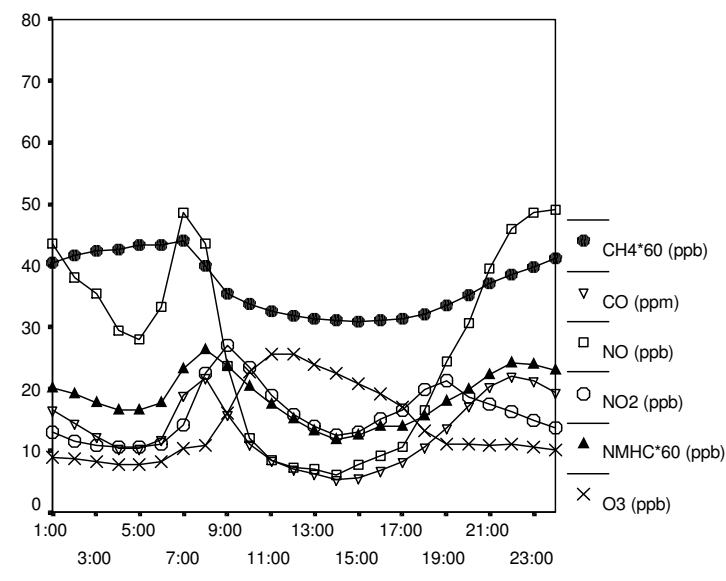

Fig. 8: Daily Average Concentration of Pollutants During the Dec-Mar Period at Station 2 In 1996

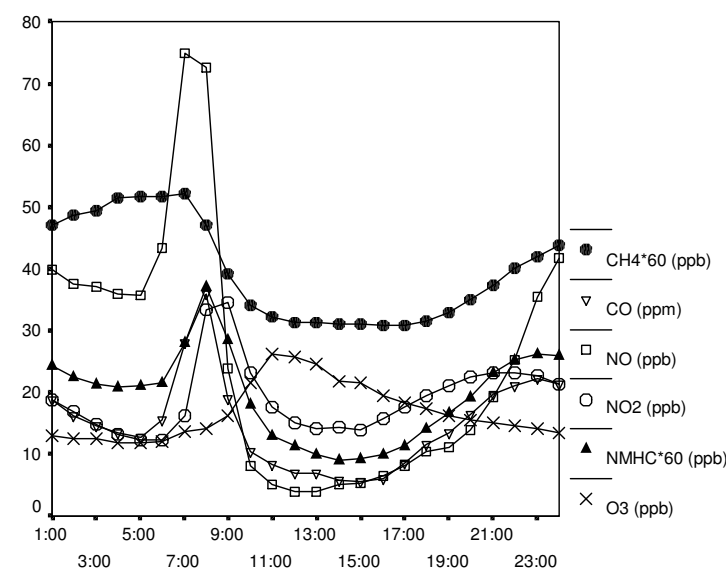

Fig. 9: Daily Average Concentration of Pollutants During the Apr-Aug Period at Station 2 in 1996

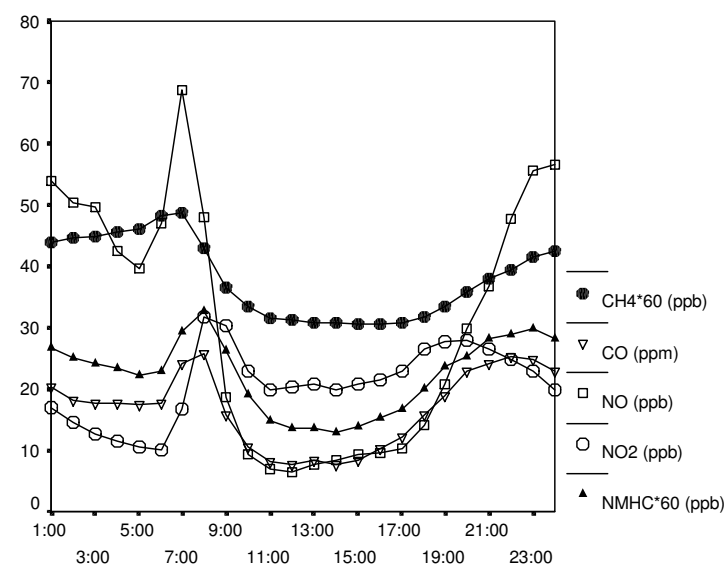

Fig. 10: Daily Average Concentration of Pollutants During the Sep-Nov Period at Station 2 in 1996

$\mathrm{CH}_{4}$ and NMHC. Thus, for the analysis of ozone precursors $\left(\mathrm{NO}, \mathrm{NO}_{2}, \mathrm{CO}, \mathrm{CH}_{4}, \mathrm{NMHC}\right.$ and $\left.\mathrm{O}_{3}\right)$, the 1996 data from stations 2, 3 and 4 were used.

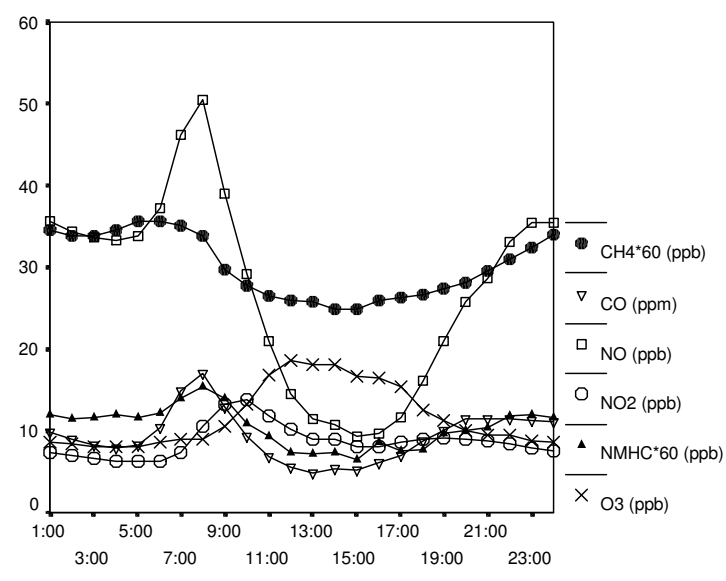

Fig.11: Daily Average Concentration of Pollutants During the Dec-Mar Period at Station 3 in 1996

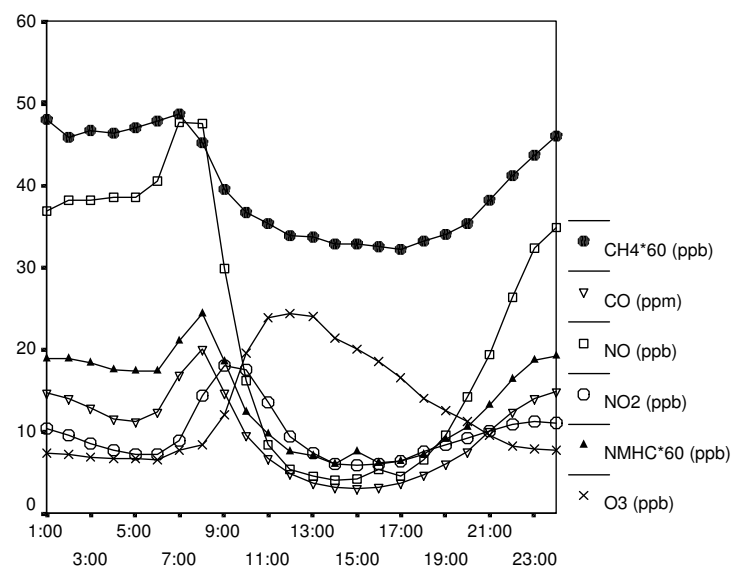

Fig.12: Daily Average Concentration of Pollutants During the Apr-Aug Period at Station 3 in 1996

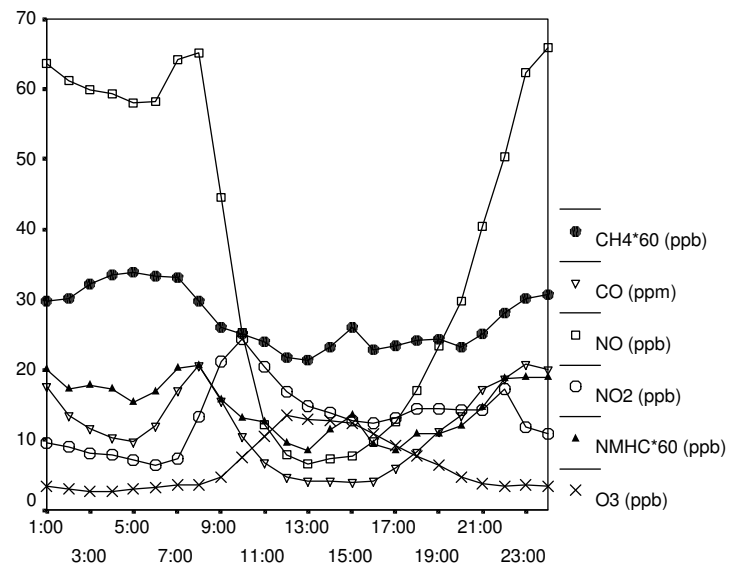

Fig. 13: Daily Average Concentration of Pollutants During the Sep-Nov Period at Station 3 in 1996

The analysis was done for each seasonal period, wet season (Dec-Mar), dry season (Sep-Nov) and transition period (Apr-Aug). 
Am. J. Environ. Sci., 1(2): 110-118, 2005

Table 7: Number of Hours Exceeding 100 ppb at Stations 2, 3, and 7 (1996-1999)

\begin{tabular}{|c|c|c|c|c|c|c|c|c|c|c|c|}
\hline & \multicolumn{2}{|c|}{1996} & \multicolumn{3}{|c|}{1997} & \multicolumn{3}{|c|}{1998} & \multicolumn{3}{|c|}{1999} \\
\hline & No. 2 & No.3 & No. 2 & No.3 & No.7 & No. 2 & No.3 & No.7 & No. 2 & No.3 & No.7 \\
\hline Jan & 0 & 0 & 0 & 0 & - & 0 & 0 & 0 & - & - & 0 \\
\hline Feb & 0 & 0 & 0 & 0 & - & 0 & 0 & 0 & - & - & - \\
\hline Mar & 0 & 0 & 0 & 0 & - & 2 & 0 & 62 & 0 & - & 0 \\
\hline Apr & 0 & 0 & 0 & 0 & - & 0 & 0 & 42 & - & - & 0 \\
\hline May & 5 & 0 & 0 & 7 & - & 0 & 0 & 178 & - & 0 & 0 \\
\hline Jun & 6 & 1 & 0 & 8 & 0 & - & 2 & 68 & - & 1 & 2 \\
\hline Jul & - & 4 & 0 & 19 & 171 & 4 & 1 & 41 & 1 & 0 & 0 \\
\hline Aug & - & 0 & 0 & 6 & 0 & - & - & 92 & 9 & 0 & 0 \\
\hline Sept & - & 0 & 2 & 2 & 1 & - & - & 84 & 6 & 0 & 0 \\
\hline Oct & - & 0 & 0 & 0 & 10 & - & - & - & 1 & - & 0 \\
\hline Nov & - & 0 & 0 & - & 4 & - & - & - & - & - & 0 \\
\hline Dec & 0 & 0 & 0 & - & 0 & 262 & - & 0 & 1 & - & 0 \\
\hline
\end{tabular}

Figure 8-13 presents the diurnal variation of pollutants during 1-year monitoring in 1996. The diurnal cycle of pollutants is typically shown for polluted urban areas. Indeed, this pattern is almost similar to the diurnal pattern of photochemical pollutants in Bangkok [5].

When the morning rush hours begin at around 7.00 a.m. to 8.00 a.m.; $\mathrm{CO}, \mathrm{NO}, \mathrm{NMHC}$ and $\mathrm{CH}_{4}$ also reaches its peak at around 8.00 a.m. due to emissions from traffic. $\mathrm{NO}$ peaks at around 7.00 a.m., while $\mathrm{NO}_{2}$ peaks at around 9.00 a.m. (about two hours after NO). NO concentration drops fast after 8.00 a.m. (after sunrise) as $\mathrm{O}_{3}$ increases reaching its highest at around 11.00-13.00. $\mathrm{CO}, \mathrm{NMHC}, \mathrm{CH}_{4}$ and $\mathrm{NO}_{2}$ also drop when $\mathrm{O}_{3}$ reaches its maximum during the afternoon hours. The reduction of these pollutant concentrations should be caused by the photochemical reactions that consume the pollutants such as reactions of pollutants with $\mathrm{OH}$ and $\mathrm{HO}_{2}$ radicals and the pollutant dispersion factors such as mixing height and wind speed. As the boundary layer increases gradually due to convective heating during noon hours, the mixing of air in the lower heights with air in the higher heights causes pollutants to be ventilated upwards [5]. The local wind may also contribute to the pollutant dilution.

In the afternoon towards evening, the pollutant concentrations increase steadily as the traffic peaks again but the photochemical production of $\mathrm{O}_{3}$ ceases due to a minimum-to-zero solar radiation. As the traffic subsides, the concentrations of $\mathrm{NO}, \mathrm{NO}_{2}, \mathrm{NMHC}$ and $\mathrm{CO}$ decrease slowly during night hours until before dawn. Interestingly, $\mathrm{CH}_{4}$ continues to increase slightly in the early hours, which may be contributed from other sources than road transport, i.e. natural, fossil-fuel related and biospheric carbon sources.

In urban centers, when $\mathrm{NO}_{\mathrm{x}}$ predominates over VOC, the $\mathrm{OH}-\mathrm{NO}_{2}$ reaction will remove $\mathrm{OH}$ radicals retarding the further $\mathrm{O}_{3}$ production. Because $\mathrm{OH}$ reacts more rapidly with $\mathrm{NO}_{2}$ than with VOCs, $\mathrm{NO}_{\mathrm{x}}$ tends to be removed faster than VOCs. In the absence of fresh $\mathrm{NO}_{\mathrm{x}}$ emissions, $\mathrm{NO}_{\mathrm{x}}$ is depleted more rapidly leading to increasing ratio of $\mathrm{VOC}$ to $\mathrm{NO}_{\mathrm{x}}$. As a result, $\mathrm{OH}$ reacts preferentially with VOCs to keep the ozone-forming cycle going [1]. This chemistry plays an important role in the temporal variations of ozone. However, the ratio of $\mathrm{VOC}$ to $\mathrm{NO}_{\mathrm{x}}$ concentration was not evaluated in this study due to limited VOCs data.

Pollutant daily maximum and average concentrations at station 2 are generally higher than at station 3 for all seasonal periods. Daily average value of $\mathrm{NO}, \mathrm{NO}_{2}$, NMHC, $\mathrm{CH}_{4}$ and $\mathrm{CO}$ at station 2 during the Dec-Mar period are $26.94 \pm 15.65 \mathrm{ppb}$ (average \pm 1 SD), $15.94 \pm 4.47 \mathrm{ppb}, 1114.93 \pm 250.5 \mathrm{ppb}, 2213 \pm 287.28 \mathrm{ppb}$ and $13.11 \pm 5.54 \mathrm{ppm}$ respectively; as compared to values at station 3 which are $27.4 \pm 12.02 \mathrm{ppb}, 8.7 \pm 2.02$ $\mathrm{ppb}, 631.15 \pm 145.07 \mathrm{ppb}, \quad 1810.8 \pm 234.87 \mathrm{ppb}$ and $9.33 \pm 3.10 \mathrm{ppm}$ respectively. Station 2 is located downwind of station 3 during wet season when westerly wind predominates transporting pollutant-enriched air masses to station 2. In the dry season, wind is mostly from NE bringing air masses from biomass burning in the nearby area (Bekasi) to station 2.

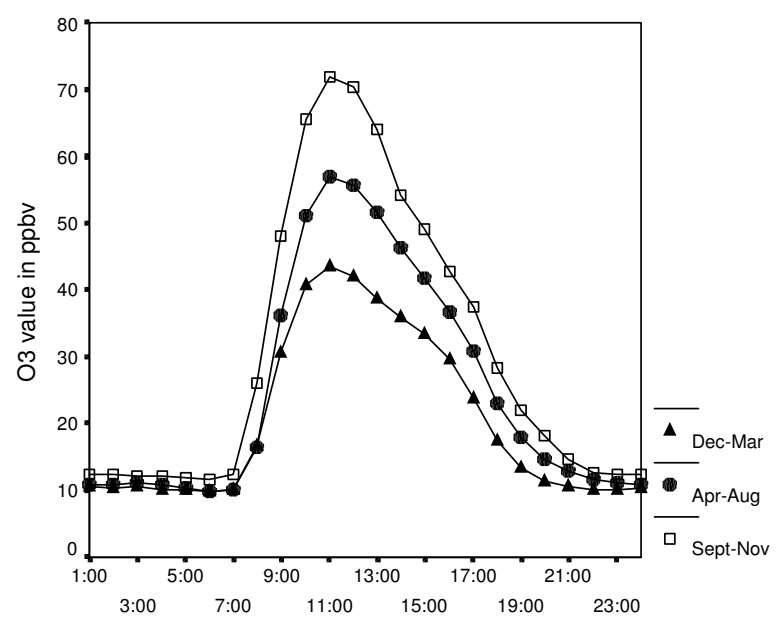

Fig. 14: Diurnal $\mathrm{O}_{3}$ Concentration Averaged for 3 Stations During Wet Months (Dec-Mar), Transition Period (Apr-Aug) and Dry Months (Sept-Nov) in 2001-2002 
This shall explain why higher pollutant concentrations are found in station 2 as compared to station 3, besides the fact that station 3 is located near to the coastal area. Daily average value of pollutants is generally higher in dry months. Figure 14 exhibits a comparison of diurnal $\mathrm{O}_{3}$ concentration during wet season, transition period and dry season using the 2001-2002 data. It is clearly shown that the Sep-Nov period records the highest diurnal variation of $\mathrm{O}_{3}$ concentration.

\section{CONCLUSION}

Photochemical smog pollution potential in Jakarta metropolitan area is high due to the high traffic emissions of ozone precursors and the favorable surface meteorological conditions, i.e. warm temperature, high solar radiation and calm wind conditions. Over the two-year period from 2001 to 2002, the ground-level ozone indicates an upward trend. The trend remains to be seen in the future as more data is made available. Despite the frequent missing database, which produces uncertainty in analysis, ozone episodes are potentially detected at downwind area off the city center. Further investigation is needed with regard to the transport of ozone and its precursors over the larger area of Jakarta and Bodetabek.

The seasonal variations of ozone illustrate the effect of local meteorological conditions and regional monsoons on ozone formation and accumulation. Ozone level is highest in the dry season (September-November) and is lowest in the wet season (December-March). Correlation between ozone level and meteorological attributes (solar radiation, relative humidity and temperature) is significant. The lower ozone level at curbside stations reflects the destruction of ozone by NO, which is emitted from traffic sources. The diurnal variations of ozone and its precursors are clearly demonstrated and are typical for polluted urban areas. Improvement of the database of air quality monitoring is very critical for Jakarta. Areas of improvement shall include the development of national guidelines on the standard procedures of air quality monitoring including site location, instrumentation, quality assurance and statistical procedures for data analysis.
The local government implementation plans on collection and analysis of data and inventorying emissions from pollution sources is a key to the identification and selection of emissions control measures. This will lead to development of efficient and cost-effective control strategy.

\section{ACKNOWLEDGMENTS}

Special acknowledgments are extended to the Environment Provincial Office of DKI Jakarta (BPLHD DKI), Environmental Management Center in Serpong (EMC), Research and Development Center of the National Atomic Agency (BATAN) in Serpong and the Bureau of Statistics for kindly providing necessary related data.

\section{REFERENCES}

1. Stern, A.C., H.C. Wohlers, R.W. Boubel and W.P. Lowry, 1973. Fundamentals of Air Pollution. Academic Press, Inc., New York.

2. Seinfeld, J.H., 1998. Atmospheric Chemistry and Physics. John Wiley and Sons, Inc., New York.

3. Japan International Cooperation Agency (JICA), Environmental Impact Management Agency (BAPEDAL) the Republic of Indonesia, 1997. The study on the integrated air quality management for Jakarta metropolitan area. Final Report, volume 2, Supporting Report. Nippon Koei Co., Ltd., Suuri keikaku Co., Ltd.

4. Chan, L.Y., H.Y. Liu, K.S. Lam, T. Wang, S.J. Oltmans and J.M. Harris, 1998. Analysis of the seasonal behavior of tropospheric ozone at Hongkong. Atmospheric Environment, 32: 59-168.

5. Zhang, B.N., Kim Oanh, N.T., 2002. Photochemical smog pollution in the Bangkok Metropolitan Region of Thailand in relation to $\mathrm{O}_{3}$ precursor concentrations and meteorological conditions. Atmospheric Environment, 36: 4211-4222. 